\title{
IS ER WEL EEN MARK?
}

Met zijne gewone scherpzinnigheid heeft de Minister van Binnenlandsche Zaken, de heer Heemskerk, in de zitting der Tweede Kamer van 5 Maart 1884, voorspeld, dat bovenstaande vraag telkens zou worden gedaan bij iedere procedure over verdeeling van Markgronden, indien de staat, behoorende bij het toen aanhangige wetsontwerp betreffende de verdeeling van Markgronden, werd weggelaten. Met een enkel woord zij herinnerd, dat achtereenvolgens twee wetsontwerpen zijn ingediend, waarbij een staat was gevoegd van onverdeelde grouden, die de wetgever als Marken meende te moeten aanwijzen. Het eerste ontwerp was van do ministers Moddermau, Klerck en Pijnacker Hordijk, en werd reeds in Mei 1882 ingediend; volgens het afdeelingsverslag was de ontvangst bij de meerderheid der Tweede Kamer gunstig en werden ook geen overwegende bedenkingen aangevoerd tegen den staat bij art. 1 gevoegd. Geen wonder dus, dat het inmiddels opgetreden ministerie Heemskerk alle anleiding vond om het anhangige wetsontwerp op de Markgronden - dat geenerlei politiek karakter droeg, al noemde de heer Heemskerk het ook tot ergernis van sommige liberalen "antirevolutionnair" - te handhaven. Met groote welwillendheid werd aan vele bezwaren te gemoet gekomen en in den staat werden onderscheidene wijzigingen gebracht naar aanleiding van de opmerkingen in het afdeelingsverslag; bij de Memorie van Beantwoording door de nieuwe ministers opgemaakt, werd een gewijzigd wetsontwerp ingediend in November 1883. In de zitting van 4 Maart $1884 \mathrm{kwam}$ het wetsontwerp in behandeling, en al spoedig bleek, dat de Kamer "om" was. Er onstond een storm tegen de wet zooals niemand had voorzien, en bij lezing der discussies weet men niet wat treffender is: de warme verdediging van regeeringszijde, of de uitéénloopende meeningen der leden. Er zijn allerlei beginselen, theoriën, stelsels, te recht en te onrecht, bij te pas gebracht. De belangen der kleine grond- 
bezitters moesten verdedigd worden tegenover het eigenbelang van den grooten grondbezitter; het scheen alsof de regeering een daad van het grootste onrecht op het oog had, vooral door den staat warop de Markgronden vermeld stonden. Sommige leden gingen zelfs zó́ ver, van zich diets te maken, dat de op dien staat voorkomende gronden verdeeld moesten worden. De staat was echter niet impératief voor do verdeeling, maar indien eigenaren van de aldaar voorkomende gronden verdeeling wenschten, dan zou door dien staat de procedure over de vraag , of de te verdeelen gronden een mark zijn" worden voorkomen. Dat uit te maken, zeide men nu daartegen, behoort alleen bij den rechter te huis, deze moest daarover beslissen, en, summa summarum, de staat werd verworpen. Wel moet de regeering ernstig doordrongen zijn geweest van de wenschelijkheid en het belang van dit wetsontwerp, daar zij zich niet heeft laten afschrikken, maar gevolg heeft gegeven aan den wensch door de heeren Verniers van der Loeff en van der Kaaij na de stemming over den staat uitgesproken, om het ontwerp andermaal in te dienen zonder den staat. Dit geschiedde in Maart 1885. Nu heette het in het afdeelingsverslag weder, dat thans het doel der wetsvoordracht niet zou worden bereikt, omdat de deelgerechtigden zouden worden afgeschrikt door de procedure over de vraag of gronden een mark vormen. Nogmaals bracht de regeering eenige wijzigingen aan en diende in November van genoemd jaar het gewijzigde ontwerp in, dat eindelijk in April 1886 in behandeling kwam en met een zeer geringe verandering werd aangenomen.

Van verschillende zijden is tijdens de langdurige onderhandelingen en de discussies over de verschillende wetsontwerpen gewezen op de belangrijke gevolgen die zij, tot wet verheven, zouden kunnen hebben, daar het niet te voorzien was in hoe uitgestrekten zin de bepalingen van die wet zouden kunnen worden toegepast en zonderling is het althans, dat de minister, aan wiens zorg de belangen van den landbouw speciaal zijn toevertrouwd, zich van het tot stand komen dezer wet, die toch in de eerste plaats den landbouw raakt, al zeer weinig schijnt te hebben aangetrokken. Gelukkig dat de Ministers van Binnenlandsche Zaken en van Justitie niet geaarzeld hebben, ter wille van de belangen van den landbouw, over ernstige historische en juridische bedenkingen heen te stappen. $\mathrm{Na}$ de aanneming toch van de tegenwoordige wet is het volstrekt niet meer noodig te onderzoeken of de gronden die men wenscht te verdeelen een Mark zijn, 
maar heeft men alleen te vragen of zij beantwoorden aan de definitie gegeven in art. 1 der wet ter bevordering van de verdeeling van Markgronden en daardoor heeft de regeering met groote handigheid de moeielijkheid door den Heemskerk voorzien indien de staat op art. 1 verviel, toch nog uit den weg geruimd, "want" - zeide de minister van Justitie in de zitting der Tweede Kamer van 15 April jl. - ${ }_{n}$ want in art. 1 wordt bepaald wat onder marken wordt verstaan. Volgens dat artikel nu, wordt daaronder niet alleen verstaan die oudere mark, dat publiekrechtelijk lichaam dat niet meer als zoodanig bestaat, maar ook het gemeenschappelijk bezit, zoorls men dit in Friesland noemt de meenscharen, meenten of iets dergelijks, eene soort van gemeenschappelijk bezit, dat niets te maken heeft met marken. „De regeering heeft van den aanvang at gezegd: laat ons die quaestie of de onverdeelde eigendom is een zedelijk lichaam, eene maatschap of vennootschap, laten rusten en hier alleen aannemen, dàt er een gemeenschappelijk eigendom wordt bezeten. Hoe of dat bu genoemd mag worden doet er niets toe."

De wetgevende macht heeft zich met die beschouwing vereenigd, door de onveranderde anneming van artikel 3 , zoodat, wanneer den rechter een eisch tot verdeeling van onverdeeld grondbezit krachtens de wet op de Markgronden wordt voorgelegd, hij geen onderzoek zal behoeven te doen naar de kenmerken van die gronden als Markgronden, maar alleen zal behoeven te vragen: voldoen zij aan de eischen gesteld in de wet ter bevordering van verdeeling van Markgronden.

En welke zijn die eischen? Geen andere dan dat de gronden nvan oudsher in onverdeelden eigendom bezeten worden onder do namen van enz." Er moet dus zijn: onverdeeld grondbezit van oudsher en een naam waaronder die gronden bekend zijn. Meer is niet noodig. Alle quaesties over historische en juridische kenmerken, alle vragen over economisch, algemeen of bijzonder belang, alle geschilpunten over het oordeel en nut voor den landbouw, enz. zijn eenvoudig afgesneden; als de gronden van oudsher in onverdeelden eigendom onder een bijzonderen naam bezeten worden, moeten zij, indien ook slechts éen mede-eigenaar dit verlangt, verdeeld worden. Tot de zoo ruime definitie in art. 1 vervat, is de regeering slechts langzamerhand gekomen tengevolge van de langdurige onderhandelingen met de commissie van rapporteurs en de discussien in de Kamer. Aanvankelijk toch was de voorgestelde wet meer uitsluitend toepasselijk op zoodanige gronden 
die als Marken bekend stonden of als zoodanig konden worden aangemerkt, maar allengs bleek het, dat er in ons land nog aanzienlijke uitgestrektheden gronds in onverdeelden eigendom bezeten worden, die misschien niet den toets van de zuivere definitie van Markgronden zouden kunnen doorstaan en die toch volgens de regelen van het Burgerlijk Recht niet zouden kunnen worden verdeeld tengevolge van den zeer ingewikkelden toestand waarin door verloop van tijd de uitoefening van het eigendomsrecht is geraakt.

Om een concreet geval aan te halen, dat wellicht ook voor de eventueele verdeeling van andere gronden belang kan hebben, wijs ik op het Vlijmensche veld of „Meerland" onder Vlijmen, en op de Engelsche slagen onder Engelen.

Oorspronkelijk hebben die gronden een gemeenschappelijk eigendom van ongeveer 221 hectaren gevormd onder het bestuur van "gequalificeerde en beëedigde Schaermeesters" en werd daarvoor den 4de Juni 1733 een reglement vastgesteld op een ${ }_{n}$ Vergadering belegt door den Schout van Vlijmen nevens de Regeerende Schaermeesters van de Slaegen en Meerland, gelegen onder de Heerlijklijkheden Engelen en Vlijmen, van de Ingelanden ofte geërfdens ten huyze van de kinderen van Joris de Zeeuw tot Vlijmen voorsz."

De toepassing van dit reglement schijnt aan de schaarmeesters veel moeielijkheden te hebben veroorzaakt, waarom zij aan Schout en Schepenen van Engelen en Vlijmen authorisatie hebben govraagd om zelven te mogen arresteeren en boeten te heffen, wat hen werd toegestaan bij ordonnantie van 3 Junij 1733.

Een geschil over het aandeel van de gemeente Vlijmen in die gronden werd vereffend bij eene transactie den 24 Mei 1735 gesloten, waarbij aan de gemeente Vlijmen zes scharen werden toegekend.

De schaarmeesters werden door schout en schepenen van Vlijmen beëedigd en waren verplicht aan dezen rekening en verantwoording te doen van hun beheer.

Later zijn de Engelsche slagen ter uitgestrektheid van 59 hectaren en het Vlijmensche veld genaamd "Meerland" bevattende 162 hectaren, ieder onder een afzonderlijke commissie van administratie gekomen, en is voor Het Vlijmensche veld, door de toenmalige "gelanders" of eigenaren den 23 Mei 1852 een Reglement vastgesteld.

De scheiding tusschen De Engelsche slagen en het Vlijmensche veld is een gevolg van verschil van verschil van gevoelen tusschen 
de eigenaren, of men alles moest hooien, dan wel gedeeltelijk hooien en gedeeltelijk weiden De Engelsche slagen worden nu geheel gehooid, terwijl van het Vlijmensche veld eene helft eerst wordt gehooid en daarna geweid, en de andere helft uitsluitend geweid. Onder de eigenaren blijft echter voortdurend verschil ontaan over de vraag of men meer moest hooien of meer moest weiden; die eigenaren, thans ten getale van 112 , - of liever er zijn 112 aandeelen van verschillende grootten - hebben natuurlijk uiteenloopende belangen, en de kleinsten onder hen, die slechts enkele aren in het geheel bezitten, hebben al zeer weinig aan hun bezit, want zij hebben te weinig om zelf vee te kunnen weiden en krijgen slechts een geringe uitkeering voor hun aandeel. De algemeene onkosten toch voor grondlasten, afheining en sloten graven, inscharing, keuring van vee, aanschaf en onderhoud van stieren enz. zijn betrekkelijk zeer aanzienlijk en tot verbetering van het gemeenschappelijk bezit kan slechts zeer weinig worden gedaan. Het streven van schaarmeesters moet altijd wezen zoo min mogelijk kosten te maken, zoodat de waarde van den grond eer achteruit dan vooruitgaat, zoodat ook hier volkomen van toepassing is wat de Minister du Tour van Bellinchave in de Kamerziting van 15 April jl. zeide: ${ }_{n}$ Het is een verouderd denkbeeld, dat men de gemeenschappelijke weilanden moet behouden om de daglooners gelegenheid te geven eene koe te laten weiden.

„Ik heb in mijne jeugd in Tietjerksteradeel een zeer uitgestrekte gemeenschappelijke weide gekend, de Bergumer gemeenschap. Voor het behoud van die gemeenschap heb ik nooit eene andere reden hooren aanvoeren, dan dat argument van de kleine landbouwers.

${ }_{n}$ Welnu, jaarlijks had de verhuring plaats, en terwijl men 15 à 20 gulden weidegeld betaalde, werd de opbrengst hoe langer hoe minder, en was zij op het laatst gedaald tot 4 à 5 gulden, omdat de grond bijna geen gras meer opleverde. Thans is echter de Bergumer gemeenschap na verdeeling veranderd in eene vruchtbare plek. Niemand heeft zich nog over de verdeeling beklaagd, want zelfs de kleine arbeider heeft er voordeel van gehad, daar hij aan de verbetering heeft medegewerkt en een dagloon heeft verdiend."

Hoewel niet in zoo sterke mate, gaat het het hier eveneens: èn de opbrengst van het hooiland èn die van de weischaren vermindert en wanneer de gronden zijn verdeeld of verkocht, zal ieder het zijne terstond verbeteren en kan men vermeerdering 
van waarde te gemoet zien, terwịl de kleine eigenaren veel meer zullen hebben aan hetgeen zij voor hun aandeel in geld krijgen dan aan het behoud van hun onverdeeld aandeel.

Voor eigenaren in deze gemeenschap zal het natuurlijk zeer gemakkelijk vallen een vonnis te verkrijgen waarbij Het Vlijmensche veld wordt aangewezen te vallen onder de bepalingen der wet op de Markgronden, want men heeft hier van ondsher onverdeelde

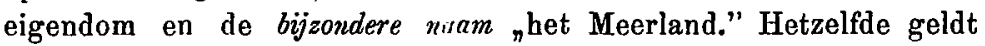
voor de Engelsche slagen, en zelfs indien men had vastgehouden aan de oorspronkelijke definitie van Markgronden, dan nog hadden de hedoelde gronden daaraan voldaan, want het is duidelijk dat hier oorspronkelijk een publiekrechterlijk karakter aanwezig was, dat later door een privaatrechterlijk is vervangen. Ware in art. 1 de definitie behouden, dat de gronden moesten behooren. aan "eenig genootschap", dan zou het in vele gevallen bezwaarlijk zijn geweest onverdeelde gronden te brengen onder die bedoeld in de Markenwet, doch nu dat criterium is vervallen, zal menig onverdeeld grondbezit op grond van die wet kunnen worden verdeeld, al heeft het ook niet, zooals het Vlijmensche veld vóor zich, dat het reeds door de regeering als Markgrond was aangewezen door plaatsing op den staat die bij art. 1 van de beide eerste ontwerpen was gevoegd.

Even gemakkelijk als nu de vraag is uit te maken of eenig onverdeeld eigendom Markgrond is volgens de bedoeling van do tegenwoordige wet, even eenvoudig is de methodus procedendi, zoodat men mag aannemen dat spoedig tot verdeeling van veel onverdeeld grondbezit zal worden overgegaan, waardoor niet alleen het belang van vele eigenaren in het bijzonder, maar ook van het algemeen zal worden bevorderd.
Vlijmen.
W. J. N. LANDRÉ.

ECoN. 1886. 